\title{
MULTINATIONAL CORPORATIONS' INTERNATIONAL MARKETING IN THE FOCUS OF THE GLOBAL REGIONALIZATION PROCESS
}

\author{
Sviatoslav Zhukov and Olesia Diugowanets
}

\begin{abstract}
Modern international economic relations are characterized by active integration, internationalization and globalization. All of them affect the political, economic, social and cultural aspects of people's lives in different countries, as well as the scientific and technological development of national economies. The prospects for expanding the scale of production and markets with a lifelong problem of resource provision remain important. The latter affects the intensification of competition among multinational corporations, the main tool of which is to reduce production costs by moving production to countries with the necessary resources and cheap labour. This leads to the expansion of the TNCs' network in the world market and encourages adaptability to national markets, and will ensure the sale of products and profits. A decisive place in the TNCs' activities belongs to the use of international marketing based on the opposite processes, e.g. globalization and regionalization. The purpose of the article is to generalize theory and practice, identify trends and establish interdependencies among the processes of globalization, regionalization and the use of types of TNCs' international marketing. The research used such methods as general, materialistic, comparative, the method of comparative analysis, the method of displaying research results in graphical and tabular form, system approach, analysis, synthesis, induction, deduction, abstraction, modelling, and comparison. As a result, the modern development of globalization, regionalization and their hybrid known as global regionalization (glocalization) is studied; the reasons and preconditions of changes in the TNCs' strategic orientation in the context of current trends in the process of global regionalization are identified; the directions of reorientation of the TNCs' international marketing strategy from local marketing to global marketing are determined; the use of such types of international marketing as cascade, global and transnational, is characterized and substantiated. The study came to the following conclusions: a modern positive phenomenon in the TNCs' development is international marketing in the context of global regionalization, as an effective and promising hybrid of two modern trends of globalization and localization (regionalization); TNCs should reorient from a global business strategy to a transnational one, adhering to the principle of "global and local thinking", using international marketing, adhering to a global marketing strategy; studies of cascade, global and transnational types of international marketing have shown significant differences in cascade and global types of marketing, and transnational marketing is characterized by mediocrity of most indicators, which indicates the rationality of its use.
\end{abstract}

Keywords: globalization, localization, regionalization, global regionalization, glocalization, transnational corporation, international marketing, cascade marketing, global marketing, transnational marketing

JEL Classification: F01, F61, M31 


\section{Authors:}

\section{Sviatoslav Zhukov}

Uzhhorod National University, 46 Pidhirna St., Uzhhorod, Ukraine, 88000

E-mail: zhukgiga@gmail.com

https://orcid.org/0000-0002-0499-7990

\section{Olesia Diugowanets}

Uzhhorod National University, 46 Pidhirna St., Uzhhorod, Ukraine, 88000

E-mail: lables@ukr.net

https://orcid.org/0000-0003-2933-4306

Citation: Zhukov, S., \& Diugowanets, O. (2020). Multinational Corporations' International Marketing in the Focus of the Global Regionalization Process. Virtual Economics, 3(4), 188-210. https://doi.org/10.34021/ve.2020.03.04(10) 


\section{Introduction}

At the current stage, the world economy and international economic relations are characterized by the intensification of integration, internationalization and globalization, that determine the human's life quality and are the locomotive of political, economic and cultural world processes. At the same time, there is a rapid growth of productive forces due to comprehensive scientific and technological development, which affects the borders of national economies, that have become narrow. All mentioned above, on the one hand, leads to the expansion of production and markets, and on the other hand it has created a problem of resource provision (Shchetynin, 2011). The global problem of resources had been considered as an environmental or economic problem till the recent times, and then it was recognized as the resource availability problem (exhaustibility, inventory balances), where it is measured by the ratio between reserves and consumption (Koriava, 2018).

The problem of resource provision increases competition between monopolies, mainly transnational corporations (TNCS), and requires production costs reduction, mainly by relocating production to poorer countries where resources and cheap labour are needed. This became the basis for expanding the network of own productions in the world economy and using the factor of adapting to the specific features of national markets, which will ensure the sale of manufactured products and, accordingly, profits (Shchetynin, 2011).

An important place in the TNCs' activities belongs to the international marketing management at all levels of economic activity, which requires the use of new marketing approaches, while taking into account two opposite modern processes known as globalization and regionalization.

Rapid changes in the current internationalization processes of economic relations and globalization of the world economy require in-depth study of the impact of globalization and regionalization on international marketing, in particular, the development of its strategy and management. This formed the basis for formulating the purpose of the article, namely: systematization, extrapolation and a combination of two important theoretical and practical areas of research: global regionalization (glocalization) as a factor in the formation of the strategy of TNCs' international marketing and typification of TNCs' international marketing, depending on the degree of impact on them of the processes of globalization and regionalization.

\section{The Literature Review}

Scientific research in the domain of globalization, regionalization and glocalization has been conducted by many scientists from different countries (Featherstone et al., 1995; Honcharova, 2009; Kudryashova, 2007; Shavkun, 2008; Spiegler, 2000; Albrow \& King, 1990; Ball et al., 2003; Khondker, 1994; Holt et al., 2004; Bogachov et al., 2020; Boiko et al., 2019; Czyżewski et al., 2019; Chygryn et al. 2020; Dalevska et al., 2019; Dementyev \& Kwilinski, 2020; Drozdz et al., 2019; 2020; Dzwigol, 2019a; 2019b; 2020a; 2020b; 2020c; Dzwigol \& Wolniak, 2018; 
Dzwigol \& Dźwigoł-Barosz, 2018; 2020; Dzwigol et al., 2019a; 2019b; 2019c; 2020a; Furmaniak et al., 2018; 2019a; 2019b; Kharazishvili et al., 2020; Kondratenko et al., 2020; Kuzior et al., 2020; Kwilinski, 2017; 2018a; 2018b; 2018c; 2018d; 2019; Kwilinski et al., 2019a; 2019b; 2019c; 2019d; 2019e; 2019f; 2019g; 2020a; 2020b; 2020c; 2020d; Kwilinski \& Kuzior, 2020; Kyrylov et al., 2020; Lakhno et al., 2018; Levitt, 1983; Miskiewicz, 2017a; 2017b; 2018; 2020; Miśkiewicz \& Wolniak, 2020; Pająk et al., 2016; 2017; Prokopenko \& Miśkiewicz, 2020; Saługa et al., 2020; Savchenko et al., 2019; Tkachenko et al., 2019a; 2019b; 2019c; 2019d; 2019e; Yelnikova \& Miskiewicz, 2020). However, the marketing issues focused on global regionalization, glocalization have dealt with a few scientists, among whom we can highlight the studies by (Korzh \& Zhukov, 2012a; Lamben, 1996). Their research is important, however, they do not have a sufficiently defined impact of globalization and regionalization on international marketing. Therefore, this branch of scientific research is relevant and requires some additional research.

Glocalization is a complex and poorly studied phenomenon, and from the point of view of academic science, the concept is insufficiently theorized without an appropriate theoretical school. Glocalization, on the other hand, is a popular and widespread term in the economic, social and political spheres, which is why there are attempts "to add glocalization to the socialscientific vocabulary as an analytically autonomous concept, and not as a simple appendage to globalization, cosmopolitanization or theories of global distribution (Gobo, 2016).

Chanchal Sharma states that the term officially made its way into the English language in the 1991 when it was included in the Oxford Dictionary of New Words (Sharma, 2009). According to the Oxford English Dictionary, glocalization is "the action, process, or fact of making something both global and local, specifically the adaptation of global influences or business strategies in accordance with local conditions; global localization." (Oxford University Press, 2018).

In the modern period, the term has been used in the Japanese marketing field to reflect the idea that consumers are likely to prefer localized adaptations of global products, and that cultural values are highly important in this process (Martin \& Arch, 2008).

Giampietro Gobo noted that Roland Robertson was the first scientist to introduce the concept of "glocalization" into scientific discourse in 1992. This idea has been criticized by scientists such as Ritzer (2003), Radhakrishnan (2010), but Roland Robertson argues that today there is only glocal, and we are not global and not local (Robertson, 1995). Glocal is the result of a historically long struggle between the global and the local, in which both have lost. In addition, Ritzer (2003) agrees that at one time there was a conditionally local, but with the advent of capitalism it lost the fight against globalization. When the local disappears, what is left is the glocal, because local and global are mutually exclusive, and therefore, the purely global and purely local no longer exist (Gobo, 2016).

Robertson rejects polarities between the global and the local, such as between economic globalization and local culture. Traditionally, local identities have been invented and nurtured 
mainly through contacts with others. They have been stimulated and shaped primarily by translocal interaction, comparison, and trends.

The local is fundamentally shaped by the global, but the opposite is also true, for example, the opening of national borders to trade and investment only increased the economic importance of location. Similarly, the expanding information economy did not distribute production and consumption across geographic space.

Joachim Blatter noted the following: "Glocalization, the simultaneous occurrence of both universalizing and particularizing tendencies in contemporary social, political, and economic systems. The term, a linguistic hybrid of globalization and localization, was popularized by the sociologist Roland Robertson and coined, according to him, by Japanese economists to explain Japanese global marketing strategies" (Blatter, 2007; Robertson, 1992).

Robertson's idea of the dynamics and interaction of equal two forces - global and local, is shared by Jeffrey Alexander, who states that "glocalization is very much like a refraction where the local is not annihilated or absorbed by globalization, but instead, the local shapes the global and they exist symbiotically together to create heterogeneity" (Gobo, 2016).

Anthony Giddens shares another point of view on glocalization. He suggests that there is a hierarchy between the two forces, where glocalization is a phenomenon caused by globalization, leading to the revival of local cultural identity ("local" is thus the responses to the forces that are "global") (Giddens, 2000). From this definition it is clear that the global is the main force which triggers the local manifest itself and does not imply a direct conflict between them.

Rudometoph recommends considering glocalization as an autonomous concept. The scholar argues that we should consider glocalization as an autonomous concept, and global and local forces as specific phenomena that have the ability to shape each other (Roudometof, 2016a). However, this approach cannot be said to be perfect either due to its failure to address the often unequal forces between the local and the global. Also, Roudometof sees a close affinity between glocalization and cosmopolitanization. The theory of cosmopolitanization was developed by Ulrich Beck (Beck, 2006) and he, in contrast to Rudometoph, insisted on the distinction between the concepts of "glocalization" and "cosmopolitanization", since glocalization, in his opinion, is primarily associated with the economic aspect, while cosmopolitanization includes many aspects from different spheres of social life (Roudometof, 2016b).

What we can take away from Roudometof's approach is that there is a multitude of glocalities, so that glocalization also has its own characteristics when applied to the field of marketing. In the marketing context, glocalization means the creation of products or services for the global market by adapting them to local cultures. Matusitz and Forrester defined glocalization in marketing as the idea that, in order to be successful in overseas markets, TNCs must take into account the local culture by immersing themselves in it and applying unconventional 
marketing techniques, while focusing on the culture and preferences of the country or region where the product will be sold (Matusitz \& Forrester, 2009).

According to Meyrowitz (2005), we live in "glocalities", each of which is unique in many ways, and yet each is reciprocally influenced by global trends and global consciousness.

Glocalization should not be seen as a great new phenomenon for the social sciences and humanities. Today, glocalization is the result of the globalization failure, so it is necessary to rethink the very concept of globalization itself. No treatment of glocalization can be final and comprehensive without reconsidering its relationship to its older and far more established 'sibling', namely globalisation. In the voluminous literature on globalisation, there is no shared definition of the concept and no authoritative vantage point from where to establish a simple or straightforward correlation between the global and the glocal (Gobo, 2016).

As a result of the literature review, we note that all opinions on glocalization remain incomplete and open for further discussions related to glocalization. Through this, scientists will be able to more fruitfully use this concept as a new addition to the terminology of the humanities and social sciences, and as an autonomous concept in these areas and disciplines.

\section{Methodology}

The research methodology is based on the general scientific methods of system analysis, comparison and generalization of foreign, Ukrainian and Russian studies of the problem of interaction between the processes of globalization and regionalization, as well as their impact on the TNCs' development, and on the choice of their international marketing strategy. The article used the following scientific research methods.

Materialistic dialectics (or dialectical materialism) was used: 1 ) in the first chapter in the context of the law of unity and struggle of opposites while studying the processes of globalization and regionalization; 2) in the second chapter as a method for studying the category of development - in the analysis of types of marketing.

A comparative method (comparative analysis) was used in the first chapter when comparing, establishing the general, particular and separate in such studied phenomena as globalization and regionalization, and the patterns of their further development (transformation) into the process of global regionalization (or glocalization).

The display of research results in graphical and tabular form was used in the first (Figures 1,2) and the second (Table 1) chapters of the article. Figure 1 reflects the research results and offers possible options for choosing a management decision; Figure 2 reflects the results of the study and offers four options for the international macroenvironment, each of which requires a specific organizational form of international marketing management of TNCs; Table 1 reflects the results of studying the types of marketing. 
A systemic approach: in the first chapter, global regionalization (glocalization) is investigated as an integral system, consisting of elements - globalization and regionalization, between which there is a certain set of relations and connections; in the second chapter, three factors (elements) are investigated, which are interconnected, induce a change in the types of international marketing and form an integral system of factors.

Analysis and synthesis, induction and deduction as the methods of theoretical research, were used to reveal and substantiate the phenomena of globalization, regionalization (in the first chapter) and international marketing (in the second chapter).

Abstraction. Abstractions were used: in the first chapter, from excessive detailing of the phenomena and processes of globalization and regionalization in favour of revealing the essence of global regionalization (glocalization); in the second chapter, from clarifying the essence of international marketing in favour of a detailed analysis of its types.

Simulation. This method in the first chapter outlines specific application cases for marketing strategies based on Figure 1 and specific variants of a specific organizational form of international marketing management of TNCs, based on Figure 2.

Comparison. The first chapter compares globalization and regionalization, and the second chapter compares the types of marketing.

\section{Globalization and Regionalization as the Factors of Forming TNCs' International Marketing Strategy}

Globalization is an essential process of the world economy evolution. It intensifies relations among the national economies of individual countries, affects all enterprises, regardless of their presence in the foreign markets, which allows enterprises and their countries to become embedded in the world economy, which is characterized by informational technology and economic revolution and the forming the horizontal connections in the world economic structures (Korzh \& Zhukov, 2012b).

For non-global processes taking place in recent years in the world it is likely to be characterized by a more modern term "glocalization". Roland Robertson noted that global and regional (or local) trends are complementary on the one hand, and competing with each other on the other, which makes them interact together nowadays (Featherstone et al., 1995). This approach assumes that the world economy has entered a newer "post-global" phase of evolution, called "global regionalization", which is a close combination of global and regional, where the local is an aspect of globalization and the global creates the local. The slogan "Global thinking but local acting" is appropriate to describe it (Shavkun, 2008).

Considering international marketing in relation to this slogan, we note that due to international cooperation, mainly in production, there is a strengthening of interdependence, which influenced the understanding of TNCs to take into account two opposites: globalization 
of their business using global marketing tools, and regionalization which means differences among the world countries or their integration groups, which requires application of differentiation in the regional (territorial, cross-border) marketing principle.

The breadth of covering TNCs' business activities with a focus on certain areas encourages them to form the international marketing management system more rationally and effectively. Firstly, we outline the common and priority areas for research by marketing services and departments, which are:

1) social, cultural, and domestic (different cultures and languages, differences in intellectual development and mentality, habits and traditions);

2) economic (different economic systems and the degree of openness / closeness of markets, different sales conditions, currency differences, different levels of infrastructure development and competition);

3) political and legal (different political systems, different legacy standards).

In developing a strategy for managing TNCs' international marketing, research and analysis of these areas serve as a core in deciding to use one of the opposite principles known as globalization and regionalization, or alternatively a combination of the two. Examining the practice of strategic management of international marketing, scientists have identified two opposing vectors for using marketing strategies. The first, which is more profitable due to the reduction of marketing costs (it is global marketing), is the conflict between the TNCs' desire for homogeneity and standardization of marketing approaches around the world. The second is based on the differences in national tastes of consumers from different countries, which is inherent in regional marketing. Possible options for choosing a management solution are clearly shown by Bartlett \& Ghoshal (1989) in the form of a matrix "globalization regionalization" (Figure 1).

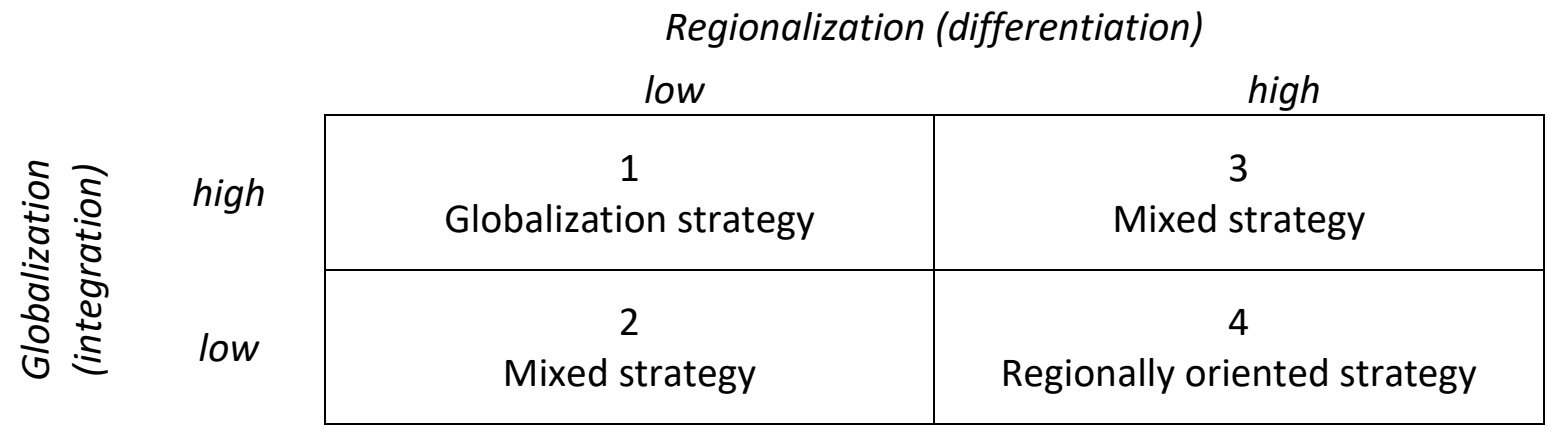

Figure 1. A Matrix "Globalization - Regionalization". Source: Bartlett \& Ghoshal (1989).

Figure 1 shows that, given the two opposing approaches mentioned above, TNCs can take advantage of a global strategy (field 1 ) through the advantages of scale and price competition, or the benefits of differentiation (field 4), which allows offering unique products to the local consumers. These fields of the matrix are the areas of simple but risky strategic marketing decisions. As an example, we note the following top-seven successful TNCs in terms of market 
capitalization as of September 2020, which adhere to field 1: "Saudi Aramco" (1,685 \$bn), "Microsoft" (1,359 \$bn), "Apple" (1,286 \$bn), "Amazon" (1,233 \$bn), “Alphabet" (919\$bn), "Microsoft" (584 \$bn), "Alibaba" (545\$bn). Market capitalization, along with annual income and total assets, is one of the methods for evaluating the investment attractiveness of a company. Using market capitalization to show the size of a company is important because the size of a company is the main factor determining the various characteristics investors are interested in, including risks (Most Valuable Companies in the World - 2020, (2020)). Other areas require less risky, but no less difficult complex solutions. Strategies for field 2 are related to standardized marketing, but situations may require decentralization of international marketing management with adaptation to the individual countries' specifics. In field 3, the needs for integration and differentiation are high, and this situation requires the integration of production in combination with the requirements of regional differentiation in international marketing. This field is characterized by a high degree of intercultural relations and is associated with "localization of global orientation", and it is the riskiest for TNCs (Panchenko, 2007).

The TNCs' solution on a global approach depends on many factors, but research and analysis of the external macro-environment are decisive here. In this case, the global benchmark itself is proposed to be assessed according to two indicators:

1) the global forces, due to many reasons, including consumer's behaviour, the benefits of economies of scale in the standardization strategy, the level of competition, etc.;

2) the local forces that draw attention to regional features e.g. the diversity of cultures, legal norms, the originality of the production and marketing system, standardization, and so on.

For these landmarks, two levels are distinguished. These are low and high, which form a twodimensional matrix represented by J.-J. Lamben (Lamben, 1996) in Figure 2 with four variants of the international macro-environment, each of which requires a specific organizational form of management of international marketing of TNCs.

\begin{tabular}{|c|c|c|}
\hline & & \\
\hline & low & High \\
\hline .ొ & $\begin{array}{l}\text { Global environment } \\
\text { (ethnocentrism) }\end{array}$ & $\begin{array}{l}\text { Transnational environment } \\
\text { (ethnopolycentrism) }\end{array}$ \\
\hline$\underline{3}$ & $\begin{array}{l}\text { Neutral international environment } \\
\text { (inert-centrism) }\end{array}$ & $\begin{array}{l}\text { Multinational environment } \\
\text { (polycentrism) }\end{array}$ \\
\hline
\end{tabular}

Figure 2. A Matrix of the International Macro-Environmental Analysis. Source: adapted from the source (Lamben, 1996).

Firstly, we are going to characterize the quadrants of the matrix from Figure 2. 
The global environment is purely standardized without the influence of local factors, and it is characterized by excessive but justified industrial security, because TNCs are high-tech organizations where responsibility and management are directed towards centralization known as ethnocentrism.

Radically opposite to the global environment is multinational, which is dominated by the characteristics of a particular country including local preferences, culture, traditions of behaviour and legal norms. In such an environment, the food industry and the hotel and restaurant business function comfortably, when tastes and culinary traditions have a strong influence on preferences and shopping habits. This forces TNCs to adapt to local characteristics and form a decentralized organizational structure known as polycentrism.

In a neutral international environment, both global and local forces are equally weak to influence the efficiency of businesses such as the cement industry and ferrous metallurgy. Its most successful name is inert-centrism.

The transnational environment is characterized by the influence of both global and local forces, which complicates the TNCs' functioning through the simultaneous use of centralization and coordination by the parent company and the support of strong regional subsidiaries.

Transformation from a global strategy to a transnational one occurs frequently; for example, the "Carlsberg" brand is a global brand that is present in more than 100 countries around the world with the same taste, label and bottle format. However, the culture of beer consuming in various countries differs, so it is more appropriate to have a transnational structure with some autonomy across countries. Another TNC "Volvo Truck", having a global organizational structure with highly centralized management and producing the same products on the world market, is not always timely adapted to regional markets, so its dealers, providing after-sales service and warranty, regularly make adjustments to the product policy (Lamben, 1996).

These examples justify solving the problems of markets' internationalization due to the need for TNCs to think globally, using global marketing strategies, and act locally, using international (regional, cross-border) marketing, which is mainly tactical in nature with a focus on local differences. In the author's previous studies, cross-border marketing is defined as "a philosophy based on the theory and practice of making managerial decisions on forming a strategy for developing cross-border markets based on research and analysis of the factors of the marketing environment in order to realize the socio-economic interests of the territory, aligning the interests of the communities on these territories, with an orientation to the needs of target groups-consumers of goods and services living on both sides of the borders" (Zhukov, 2010). However, the principle of "global thinking and local acting" implies the ability of TNCs to create products without taking into account the results of local needs analysis, trying to get them accepted worldwide later, which shows the unwillingness of TNCs to change global marketing strategy to transnational orientation. An alternative to this principle is the Procter \& Gamble's principle of "thinking both globally and locally", i.e. the development of product policy at both 
regional and global levels, which corresponds to ethnopolycentrism. Within its limits there is a so-called glocal marketing, whose strategy provides four-stage functions:

1) an analysis of local (regional) needs in a particular country;

2) globalization of the concept of goods developed locally;

3) adaptation of the product to each specific environment of the region;

4) implementation of the strategy through adapted operational marketing (Lamben, 1996).

\section{A Typification of TNCs' International Marketing Depending on the Degree of Globalization and Regionalization Influence}

The most difficult for the international marketing organization in the TNCs' activities is ethnopolycentrism (transnationalism), in which ethno- and polycentrism are equally strong. According to these two multi-vector forces, there are three types of marketing: cascade, global and transnational, and both ethnopolycentric and inert-centric can use one of three marketing types.

Determining the type of marketing provides important information about competitors and partners, which allows judging the nature of the products in terms of their competitiveness, as well as the capabilities of TNCs, as not every firm is capable of global and transnational marketing.

In the countries which are insufficiently developed, for the enterprises at the initial stage of their foreign economic activity due to their limited capabilities, primarily financial (marketing budget), it is advisable to use cascade marketing. Cascade marketing involves the consistent development of different foreign markets and marketing activities in one or more foreign markets that are not related to the domestic market. It is still prevalent in the countries with the developed market economies and in the Ukrainian enterprises (Naydenov et al., 2003). Instead, if successful in their international activities, TNCs can use all types of international marketing, which will ensure the rational use of their competitive advantages.

The transformation of marketing types from one to another depends on many reasons and is associated with the tasks facing TNCs in implementing each type of international marketing (Sobolev, 2004). There are three important factors that encourage changes in the types of international marketing.

The first factor is the dynamics of consumer's needs. In international markets, the variability and ever-increasing rate of change in customer demand, improving the quality of goods and services encourage TNCs to change the type of international marketing, for example from cascade one to another one. This is due to the fact that cascade marketing, although it is deeply adaptable to the market conditions of a particular country and meets the demands of consumers as much as possible, but due to excessive complexity and accuracy of accounting for changes in marketing, it is too slow. Therefore, the main focus of cascade marketing is not on the speed of change in consumer needs, but on the compliance of the marketing complex with the market requirements. 
While implementing the global marketing, a strategy of standardizing goods or services is implemented, and the decisive role belongs to the timely transition to another, new marketing complex in accordance with changes in consumer demand. Because of this, global marketing is characterized by a high degree of risk to meet consumer needs late and to fail to satisfy the quality market needs. As a result, in conditions of mass demand for goods and services, TNCs are moving to the use of transnational marketing.

The second factor is the desire to enter foreign markets. As the number of markets grows, TNCs are inclined to a strategy of globalization, taking into account the characteristics of individual markets. It seems that the growth of the markets' number and, accordingly, business activities using global marketing may affect the inhibition in developing TNCs. However, this cannot be allowed, as it threatens to give competitors an advantage by using the concept of transnational marketing.

Within the functioning of cascade marketing, the growth of the number of markets is less important than the profitability of foreign economic activity. This is due to different internal and external marketing complexes, and the secondary economies of scale. The opposite is the situation with the global marketing effectiveness, which is determined by the number of countries in which a standardized marketing mix is used. Therefore, it is the combined use of the benefits of cascading and global types of marketing that benefits transnational marketing and allows exploring international markets on an even larger scale.

The third factor is the TNCs' competitiveness. Improving the TNCs' competitiveness, as in previous factors, is associated with the studied types of marketing. TNCs' competitiveness is a complex concept with certain criteria (in our case - the quality of goods and services, the cost of their production, the number of international markets), which make it possible to assess the impact of types of international marketing on the TNCs' competitiveness. An indicator of increasing the level of TNCs' competitiveness is the availability of goods and services of international quality with a price available to the target market segment of the selected country. Despite the very number of international markets, even without defining their positions in them, TNCs already indicate high competitiveness in a highly competitive environment.

In order to establish the particular country's market needs, TNCs use cascade marketing, which contributes to creating goods and services of high quality. Instead, this type of marketing does not allow TNCs to save on the scale of production, and therefore they are non-competitive in price. The small number of markets compared to other types of marketing also reduces the effectiveness of cascading marketing. This is explained by the fact that the rapid change in market conditions, even in one country, often complicates the financial performance of TNCs and weakens their competitiveness in other international markets (Sobolev, 2004). 
The global marketing, in comparison with the cascade one, is able to affect positively two of the three factors of TNCs' competitiveness: a) the cost of goods (services) production; b) the number of countries whose markets the corporation enters.

At the same time, standardized products in global marketing are not always able to meet the consumers' needs best, which reduces the TNCs' competitiveness. Comparing the transnational type of marketing with the other two types, it should be noted that it reduces costs compared to cascade marketing, but not below the level of global marketing, and by adapting products to markets of different countries helps to meet market needs better. In addition, the ability to develop new markets in transnational marketing is much greater than in the global one.

Three defined factors of transition from one type of marketing to another reflect the general laws of applying the international marketing depending on the change of a market situation. However, it is problematic to define these types of marketing practically. TNCs, having performed certain tasks in foreign trade, usually use several types of marketing at the same time, or make the transition to global or transnational marketing, bypassing the cascade one. The latter is possible if relevant products or services with a high level of competition and the necessary resources are available, and contribute to the already existing positive experience of TNCs that have managed to quickly move from cascading marketing to global and transnational (e.g. software, communications, office equipment etc). It should be noted that TNCs can use one of three types of international marketing, and simultaneously combine two or three types. In the latter case, each of the types will cover a different number of markets, have different performance and be used for various purposes.

Table1. A Comparative Characteristics of the International Marketing Types

\begin{tabular}{|c|c|c|c|}
\hline \multirow[t]{2}{*}{ Indicators } & \multicolumn{3}{|c|}{ International marketing types } \\
\hline & Cascade & Global & Transnational \\
\hline 1. The level of adaptation to one foreign country & High & Low & Medium \\
\hline 2. The possibility of simultaneous distribution in several countries & Low & High & Medium \\
\hline 3. Standardization of marketing systems & $\begin{array}{c}\text { Not } \\
\text { implemented }\end{array}$ & High & Medium \\
\hline 4. Economic and political risk & Low & High & Medium \\
\hline 5. Projected economic efficiency & Low & High & Medium \\
\hline $\begin{array}{l}\text { 6. Types of international marketing with which it is most } \\
\text { combined }\end{array}$ & Transnational & Transnational & $\begin{array}{l}\text { Global, } \\
\text { cascade }\end{array}$ \\
\hline 7. Speed of reaction to the market needs & Low & High & Medium \\
\hline 8. The degree of consumer needs' satisfaction & High & Low & Medium \\
\hline 9. Speed of marketing activities & High & Low & Medium \\
\hline 10. The level of distribution among firms & High & Medium & Medium \\
\hline 11. Level of qualification of marketing staff & High & Medium & High \\
\hline 12. Marketing costs per country & High & Low & Medium \\
\hline
\end{tabular}

Source: adapted from the source (Sobolev, 2004). 
After studying international marketing, Sobolev V. (2004) made a comparative description of the three types of international marketing, which is shown in Table 1.

The research of three types of international marketing shows a fundamental difference in its cascade and global types. On the other hand, transnational marketing is characterized by the mediocrity of the values of most indicators without significant distortions in one or another direction, which gives grounds to argue about the rationality of using this international marketing type.

\section{Conclusions}

A modern positive phenomenon in developing international business in general and international marketing activities in particular is glocalization, which means an effective and promising hybrid of two modern trends known as globalization and localization (regionalization). Glocalization is an accelerator of international economic activity through adapting production and consumption of universal goods and services to the specificity of the regional market.

Given the new promising phenomenon called glocalization, it is an advisable for companies to reorient from a global business strategy to a transnational one: start from "thinking globally", carrying out strategic marketing, and continue "acting locally", conducting operational (tactical) marketing focused on specific regions.

The study showed that not all companies are ready to change the global orientation of marketing to its transnational type. The most promising strategy for global companies is the principle of "global thinking and local acting", which means the need to develop and implement marketing product policy at both regional and global levels, i.e. to adhere to a glocal marketing strategy. This is confirmed by the ratings: Fortune Global 500, the criterion of which is the company's revenue (Fortune Global 500, 2020); Global Top 100 is based on market capitalization (Global Top 100 companies, 2020); Forbes Global 2000 ranked it according to four indicators: sales, profits, assets and market value of companies (Global Top 100 companies, 2020).

In the matrix in Figure 2, four quadrants (variants) of the international macroenvironment are highlighted. Each field of the matrix has a different focus on marketing strategy. For a neutral international environment with weak influence and global and local forces, it is proposed to use the term inert-centrism.

The first chapter focuses on the fact that for TNCs, in addition to international marketing, it is advisable to use regional or cross-border marketing with a focus on local differences.

The development of two opposite but interdependent processes - globalization and localization - is promising on the authors' opinion. It means, that it will be the subject of further research and discussion in the scientific community. For some researchers, these 
processes are part of a something whole, and the relations among them are strengthened and intertwined. For the others, it is the coexistence of opposite, antagonistic, with significant contradictions among them.

The second chapter examines the types of TNCs' international marketing, depending on the strength of the impact of globalization and regionalization processes: cascading, global and transnational. However, there are no clear patterns of their use, and TNCs may use either several types of marketing at the same time or not use one of them. Three main factors of influence on changes in the types of TNCs' international marketing, changes in the priority of consumer needs, the desire to enter foreign markets, and increased competitiveness are identified.

Taking into account the comparative characteristics of the types of international marketing in the 12th indicators in Table 1, certain differences are established in the cascading and global types of marketing, and transnational marketing is characterized by mediocrity of values among most indicators, shows its rationality in use in practice.

Regarding the study of cascade, global and transnational types of international marketing, we note the significant differences in cascade and global types of marketing, and transnational marketing is characterized by mediocrity of values among most indicators, which shows its rationality in its practical use.

As a result of generalization and systematization of the theory of globalization and regionalization, as well as the practical experience of TNCs, a connection was established between global regionalization and international marketing activities of TNCs. In accordance with the purpose of the article, this made it possible to substantiate the choice of the type of international marketing for TNCs depending on the process of global regionalization.

\section{References}

Albrow, M., \& King, E. (1990). Globalization, Knowledge, and Society. London: Sage Publications.

Ball, D.A., Geringer, M., Minor, M., \& McNett, J. (2003). International Business: The Challenge of Global Competition - ninth edition. Boston: McGraw-Hill/Irwin, 478.

Bartlett, C., \& Ghoshal, S. (1989). Model of International Strategy. Study notes. Retrieved from https://www.tutor2u.net/business/reference/bartlett-ghoshal-model-internationalstrategy\#: :text=The\%20Bartlett\%20\%26\%20Ghoshal\%20Model\%20indicates,\%3A\%20local\%20r esponsiveness\%20\%26\%20global\%20integration

Beck, U. (2006). Cosmopolitan Vision. Oxford, UK: Polity. 
Blatter, J. K. (2007). Glocalization. In Mark Bevir (Ed.), Encyclopaedia of Governance (pp. 357-359). London: Sage Publications. Retrieved from http://1.droppdf.com/files/vJBYg/encyclopedia-ofgovernance.pdf

Bogachov, S., Kwilinski, A., Miethlich, B., Bartosova, V., Gurnak, A. (2020). Artificial Intelligence Components and Fuzzy Regulators in Entrepreneurship Development. Entrepreneurship and Sustainability Issues, 8(2), 487-499. http://doi.org/10.9770/jesi.2020.8.2(29)

Boiko, V., Kwilinski, A., Misiuk, M., \& Boiko, L. (2019). Competitive Advantages of Wholesale Markets of Agricultural Products as a Type of Entrepreneurial Activity: The Experience of Ukraine and Poland. Economic Annals-XXI, 175(1-2), 68-72. https://doi.org/10.21003/ea.V175-12

Chygryn, O., Bilan, Y., \& Kwilinski, A. (2020). Stakeholders of Green Competitiveness: Innovative Approaches for Creating Communicative System. Marketing and Management of Innovations, 3, 356-368. https://doi.org/10.21272/mmi.2020.3-26

Czyżewski, B., Matuszczak, A., \& Miskiewicz, R. (2019). Public Goods Versus the Farm Price-Cost Squeeze: Shaping the Sustainability of the EU's Common Agricultural Policy. Technological and Economic Development of Economy, 25(1), 82-102. https://doi.org/10.3846/tede.2019.7449

Dalevska, N., Khobta, V., Kwilinski, A., \& Kravchenko, S. (2019). A Model for Estimating Social and Economic Indicators of Sustainable Development. Entrepreneurship and Sustainability Issues, 6(4), 1839-1860. https://doi.org/10.9770/jesi.2019.6.4(21)

Dementyev, V.V., \& Kwilinski, A. (2020). Institutsionalnaya sostavlyayuschaya izderzhek proizvodstva [An Institutional Component of Production Costs]. Journal of Institutional Studies, 12(1), 100-116. https://doi.org/10.17835/2076-6297.2020.12.1.100-116

Drew, D., \& Woodside, A.G. (2008). Dochakuka, Journal of Global Marketing, 21(1), 19-32. https://doi.org/10.1300/J042v21n01_03

Drozdz, W., Miskiewicz, R., Pokrzywniak, J., \& Elzanowski, F. (2019). Urban Electromobility in the Context of Industry 4.0. Torun: Wydawnictwo Adam Marszalek.

Drozdz, W., Marszalek-Kawa, J., Miskiewicz, R., \& Szczepanska-Waszczyna, K. (2020). Digital Economy in the Contemporary World. Torun: Wydawnictwo Adam Marszalek.

Dzwigol, H. (2019a). The Concept of the System Approach of the Enterprise Restructuring Process. Virtual Economics, 2(4), 46-70. https://doi.org/10.34021/ve.2019.02.04(3)

Dzwigol, H. (2019b). Research Methods and Techniques in New Management Trends: Research Results. Virtual Economics, 2(1), 31-48. https://doi.org/10.34021/ve.2019.02.01(2)

Dzwigol, H. (2020a). Innovation in Marketing Research: Quantitative and Qualitative Analysis. Marketing and Management of Innovations, 1, 128-135. http://doi.org/10.21272/mmi.2020.1-10 
Dzwigol, H. (2020b). Methodological and Empirical Platform of Triangulation in Strategic Management. Academy of Strategic Management Journal, 19(4), 1-8.

Dźwigoł, H. (2020c). Interim Management as a New Approach to the Company Management. Review of Business and Economics Studies, 8(1), 20-26. https://doi.org/10.26794/2308-944X-2020-8-1-2026

Dzwigol, H., \& Wolniak, R. (2018). Controlling w procesie zarządzania chemicznym przedsiębiorstwem produkcyjnym [Controlling in the Management Process of a Chemical Industry Production Company]. Przemys/ Chemiczny, 97(7), 1114-1116. https://doi.org/10.15199/62.2018.7.15

Dzwigol, H., \& Dźwigoł-Barosz, M. (2018). Scientific Research Methodology in Management Sciences. Financial and Credit Activity: Problems of Theory and Practice, 2(25), 424-437. https://doi.org/10.18371/fcaptp.v2i25.136508

Dzwigol, H., \& Dzwigol-Barosz, M. (2020). Sustainable Development of the Company on the Basis of Expert Assessment of the Investment Strategy. Academy of Strategic Management Journal, 19(5), 1-7.

Dzwigol, H., Shcherbak, S., Semikina, M., Vinichenko, O., \& Vasiuta, V. (2019a). Formation of Strategic Change Management System at an Enterprise. Academy of Strategic Management Journal, 18(SI1), 1-8.

Dzwigol, H., Aleinikova, O., Umanska, Y., Shmygol, N., \& Pushak, Y. (2019b). An Entrepreneurship Model for Assessing the Investment Attractiveness of Regions. Journal of Entrepreneurship Education, 22(1S), 1-7.

Dzwigoł, H., Dzwigoł-Barosz, M., Zhyvko, Z., Miskiewicz, R., \& Pushak, H. (2019c). Evaluation of the Energy Security as a Component of National Security of the Country. Journal of Security and Sustainability Issues, 8(3), 307-317. http://doi.org/10.9770/jssi.2019.8.3(2)

Dzwigol, H., Dźwigoł-Barosz, M., \& Kwilinski, A. (2020d). Formation of Global Competitive Enterprise Environment Based on Industry 4.0 Concept. International Journal of Entrepreneurship, 24(1), 1-5.

Dzwigol, H., Dzwigol-Barosz, M., Miskiewicz, R., \& Kwilinski, A. (2020). Manager Competency Assessment Model in the Conditions of Industry 4.0. Entrepreneurship and Sustainability Issues, 7(4), 2630-2644. https://doi.org/10.9770/jesi.2020.7.4(5)

Featherstone, M., Lash, S., \& Robertson R. (1995). Glocalization: Time-Space and HomogeneityHeterogeneity. In Global Modernities (pp. 25-44). London: Sage Publications.

Fortune Global 500. (2020). Retrieved from https://fortune.com/global500/ 
Furmaniak, S., Gauden, P.A., Patrykiejew, A., Miśkiewicz, R., \& Kowalczyk, P. (2018). Carbon Nanohorns as Reaction Nanochambers - a Systematic Monte Carlo Study. Scientific Reports, 15407. https://doi.org/10.1038/s41598-018-33725-z

Furmaniak, S., Gauden, P.A., Patrykiejew, A., Miskiewicz, R., \& Kowalczyk, P. (2019a). The Effects of Confinement in Pores Built of Folded Graphene Sheets on the Equilibrium of Nitrogen Monoxide Dimerisation Reaction. Journal of Physics Condensed Matter, 31(13), 135001, 1-12. https://doi.org/10.1088/1361-648X/aaffb3

Furmaniak, S., Gauden, P.A., Patrykiejew, A., Szymański, G., Miśkiewicz, R., \& Kowalczyk, P. (2019b). In Silico Study on the Effects of Carbonyl Groups on Chemical Equilibrium of Reactions with a Polar Product Occurring under Confinement in Pores of Activated Carbons. Chemical Engineering Communications, 1-12. https://doi.org/10.1080/00986445.2019.1700115

Giddens, A. (2000). Runaway World: How Globalization is Reshaping Our Lives. Society, 38(1), 106-107.

Global Top 100 companies. (2020). June 2020 Update. 2020. Global Ranking of the Top 100 Public Companies by Market Capitalization. Retrieved from https://www.pwc.com/gx/en/services/auditassurance/publications/global-top-100-companies.html

Gobo, G. (2016). Book Review: Glocalization: A Critical Introduction. European Journal of Cultural and Political Sociology, 3(2-3). http://dx.doi.org/10.1080/23254823.2016.1209886

Holt, D.B., Quelch, J.A., \& Taylor, E.L. (2004). How Global Brands Compete. Harvard Business Review, Boston, 82(9), 68-81.

Honcharova, O.V. (2009). Poniatiino-katehoriina sutnist ta osnovni zasady hlokalizatsii. Retrieved from http://base.dnsgb.com.ua/files/journal/Formuvannya-rynkovoi-ekonomiky/FRE-2009-

22/2009_22-goncharova.pdf [in Ukrainian].

Kharazishvili, Y., Kwilinski, A., Grishnova, O., \& Dzwigol, H. (2020). Social Safety of Society for Developing Countries to Meet Sustainable Development Standards: Indicators, Level, Strategic Benchmarks (with Calculations Based on the Case Study of Ukraine). Sustainability, 12(21), 8953. https://doi.org/10.3390/su12218953

Khondker, H. (1994). Globalization Theory: A Critical Analysis. Department of Sociology Working Paper, National University of Singapore. 36.

Kondratenko, V., Okopnyk, O., Ziganto, L., \& Kwilinski, A. (2020). Innovation Development of Public Administration: Management and Legislation Features. Marketing and Management of Innovations, 1, 87-94. https://doi.org/10.21272/mmi.2020.1-06

Koriava, D.S. (2018). Hlobalna problema zabezpechennia resursamy. Retrieved from https://er.nau.edu.ua/bitstream/NAU/37772/1/\%d0\%9a\%d0\%be\%d1\%80\%d1\%8f\%d0\%b2\%d0\% b0.pdf [in Ukrainian]. 
Korzh, M., \& Zhukov, S. (2012a). Hlobalizatsiia ta internatsionalizatsiia yak umovy transformatsii marketynhovoho upravlinnia pidpryiemstvom. Aktualni problemy ekonomiky. 129(3), 64-71. [in Ukrainian].

Korzh, M., \& Zhukov, S. (2012b). Marketynhova diialnist pidpryiemstv v umovakh hlobalizatsii: monohrafiia. Kramatorsk: DDMA. [in Ukrainian].

Kudryashova, I. A. (2007). Kontseptualno-teoreticheskie osnovyi glokalizatsii mirovoy ekonomiki. Voprosyi novoy ekonomiki, 1, 1-10. [in Russian].

Kuzior, A., Kwilinski, A., \& Tkachenko, V. (2019). Sustainable Development of Organizations Based on the Combinatorial Model of Artificial Intelligence. Entrepreneurship and Sustainability, 7(2), 13531376. http://doi.org/10.9770/jesi.2019.7.2(39)

Kwilinski, A. (2017). Development of Industrial Enterprise in the Conditions of Formation of Information Economics. Thai Science Review, Autumn 2017, 85-90. https://doi.org/10.5281/zenodo.1414236

Kwilinski, A. (2018a). Mechanism of Formation of Industrial Enterprise Development Strategy in the Information Economy. Virtual Economics, 1(1), 7-25. https://doi.org/10.34021/ve.2018.01.01(1)

Kwilinski, A. (2018b). Mechanism of Modernization of Industrial Sphere of Industrial Enterprise in Accordance with Requirements of the Information Economy. Marketing and Management of Innovations, 4, 116-128. http://doi.org/10.21272/mmi.2018.4-11

Kwilinski, A. (2018c). Mechanism for Assessing the Competitiveness of an Industrial Enterprise in the Information Economy. Research Papers in Economics and Finance, 3(1), 7-16. https://doi.org/10.18559/ref.2018.1.1

Kwilinski, A. (2018d). Trends of Development of the Information Economy of Ukraine in the Context of Ensuring the Communicative Component of Industrial Enterprises. Economics and Management, 1(77), 64-70.

Kwilinski, A. (2019). Implementation of Blockchain Technology in Accounting Sphere. Academy of Accounting and Financial Studies Journal, 23(SI2), 1-6.

Kwilinski, A., Tkachenko, V., \& Kuzior, A. (2019a). Transparent Cognitive Technologies to Ensure Sustainable Society Development. Journal of Security and Sustainability Issues, 9(2), 561-570 http://doi.org/10.9770/jssi.2019.9.2(15)

Kwilinski, A., Drobyazko, S., \& Derevyanko, B. (2019b). Synergetic and Value Effects in Corporate Mergers and Acquisitions of International Companies. In Khalid S. Soliman (Ed.), Proceedings of the 34th International Business Information Management Association Conference (IBIMA) 13-14 November 2019. Vision 2025: Education Excellence and Management of Innovations through Sustainable Economic Competitive Advantage in 2019 (pp. 9467-9471). Madrid, Spain: IBIMA Publishing. 
Kwilinski, A., Dalevska, N., Kravchenko, S., Hroznyi, I., Kovalenko, I. (2019c). Formation of the Entrepreneurship Model of E-Business in the Context of the Introduction of Information and Communication Technologies. Journal of Entrepreneurship Education, 22(SI1), 1528-2651-22-S1337: 1-7.

Kwilinski, A., Ruzhytskyi, I., Patlachuk, V., Patlachuk, O., \& Kaminska, B. (2019d). Environmental Taxes as a Condition of Business Responsibility in the Conditions of Sustainable Development. Journal of Legal, Ethical and Regulatory Issues, 22(SI2) 1544-0044-22-SI-2-354: 1-6.

Kwilinski, A., Volynets, R., Berdnik, I., Holovko, M., \& Berzin, P. (2019e). E-Commerce: Concept and Legal Regulation in Modern Economic Conditions. Journal of Legal, Ethical and Regulatory Issues, 22(SI2), 1544-0044-22-SI-2-357: 1-6.

Kwilinski, A., Dzwigol, H., \& Dementyev, V. (2019f). Transnational Corporations as Entities of International Entrepreneurship. International Journal of Entrepreneurship, 23(SI4), 1-6.

Kwilinski, A., Pajak, K., Halachenko, O., Vasylchak, S., Pushak, Ya., \& Kuzior, P. (2019g). Marketing Tools for Improving Enterprise Performance in the Context of Social and Economic Security of the State: Innovative Approaches to Assessment. Marketing and Management of Innovations, 4, 172-181. http://doi.org/10.21272/mmi.2019.4-14

Kwilinski, A., \& Kuzior, A. (2020). Cognitive Technologies in the Management and Formation of Directions of the Priority Development of Industrial Enterprises. Management Systems in Production Engineering, 28(2), 119-123. http://doi.org/10.1515/mspe-2019-0020

Kwilinski, A., Vyshnevskyi, O., \& Dzwigol, H. (2020a). Digitalization of the EU Economies and People at Risk of Poverty or Social Exclusion. Journal of Risk and Financial Management, 13(7), 142. https://doi.org/10.3390/jrfm13070142

Kwilinski, A., Zaloznova, Y., Trushkina, N., \& Rynkevych, N. (2020b). Organizational and Methodological Support for Ukrainian Coal Enterprises Marketing Activity Improvement. E3S Web of Conferences, 168, 00031. https://doi.org/10.1051/e3sconf/202016800031

Kwilinski, A., Dielini, M., Mazuryk, O., Filippov, V., \& Kitseliuk, V. (2020c). System Constructs for the Investment Security of a Country. Journal of Security and Sustainability Issues, 10(1), 345-358. https://doi.org/10.9770/jssi.2020.10.1(25)

Kwilinski, A., Shteingauz, D., \& Maslov, V. (2020). Financial and Credit Instruments for Ensuring Effective Functioning of the Residential Real Estate Market. Financial and Credit Activities: Problems of Theory and Practice. 3(34), 133-140. Retrieved from https://fkd.ubs.edu.ua/index.php/fkd/article/view/3023

Kyrylov, Y., Hranovska, V., Boiko, V., Kwilinski, A., \& Boiko, L. (2020). International Tourism Development in the Context of Increasing Globalization Risks: On the Example of Ukraine's 
Integration into the Global Tourism Industry. Journal of Risk and Financial Management, 13(12), 303. https://doi.org/10.3390/jrfm13120303

Lakhno, V., Malyukov, V., Bochulia, T., Hipters, Z., Kwilinski, A., \& Tomashevska, O. (2018). Model of Managing of the Procedure of Mutual Financial Investing in Information Technologies and Smart City Systems. International Journal of Civil Engineering and Technology, 9(8), 1802-1812.

Lamben, Z.-Z. (1996). Strategicheskiy marketing. SPb.: Nauka. [in Russian].

Levitt, T., (1983). The Globalization of Markets. Boston: Harvard Business Review. Retrieved from https://hbr.org/1983/05/the-globalization-of-markets.

Matusitz, J., \& Forrester, M. (2009). Successful Glocalization Practices: The Case of Seiyu in Japan. Journal of Transnational Management, 14(2), 155-176. https://doi.org/10.1080/15475770903028696.

Meyrowitz, J. (2005). The Rise of Glocality: New Senses of Place and Identity in the Global Village. In K. Nyíri (Ed.), A Sense of Place: The Global and the Local in Mobile Communication (pp. 21-30). Vienna: Passagen.

Miskiewicz, R. (2017a). Knowledge in the Process of Enterprise Acquisition. Progress in Economic Sciences, 4, 415-432. https://doi.org/10.14595/PES/04/029

Miskiewicz, R. (2017b). Knowledge Transfer in Merger and Acquisition Processes in the Metallurgical Industry. Warsaw: PWN.

Miskiewicz, R. (2018). The Importance of Knowledge Transfer on the Energy Market. Polityka Energetyczna, 21(2), 49-62. http://dx.doi.org/10.24425\%2F122774

Miskiewicz, R. (2019). Challenges Facing Management Practice in the Light of Industry 4.0: The Example of Poland. Virtual Economics, 2(2), 37-47. https://doi.org/10.34021/ve.2019.02.02(2)

Miskiewicz, R. (2020). Internet of Things in Marketing: Bibliometric Analysis. Marketing and Management of Innovations, 3, 371-381. http://doi.org/10.21272/mmi.2020.3-27

Miskiewicz, R. (2020a). Efficiency of Electricity Production Technology from Post-Process Gas Heat: Ecological, Economic and Social Benefits. Energies, 13(22), 6106. https://doi.org/10.3390/en13226106

Miśkiewicz, R, \& Wolniak, R. (2020b). Practical Application of the Industry 4.0 Concept in a Steel Company. Sustainability, 12(14), 5776. https://doi.org/10.3390/su12145776

Most Valuable Companies in the World - 2020. (2020). Retrieved from https://fxssi.com/top-10-mostvaluable-companies-in-the-world. 
Naydenov, N., Sandrigaylo, L., \& Sandrigaylo, A. (2003). Mezhdunarodnyiy marketing: Opornyiy konspekt lektsiy. Syiktyivkar: SSS. [in Russian].

Oxford University Press. (2018). Retrieved from https://www.oed.com/view/Entry/248938.

Pająk, K., Kamińska, B., \& Kvilinskyi, O. (2016). Modern Trends of Financial Sector Development under the Virtual Regionalization Conditions. Financial and Credit Activity: Problems of Theory and Practice, 2(21), 204-217. https://doi.org/10.18371/fcaptp.v2i21.91052

Pająk, K., Kvilinskyi, O., Fasiecka, O., \& Miskiewicz, R. (2017). Energy Security in Regional Policy in Wielkopolska Region of Poland. Economics and Environment, 2(61), 122-138.

Panchenko, Ye. (2007). Mizhnarodnyi menedzhment: navch.-metod. posib. dlia samost. vyvch. dysts. K.: KNEU. [in Ukrainian].

Prokopenko, O., \& Miśkiewicz, R. (2020). Perception of "Green Shipping" in the Contemporary Conditions. Entrepreneurship and Sustainability Issues, 8(2), 269-284. https://doi.org/10.9770/jesi.2020.8.2(16)

Radhakrishnan, S. (2010). Limiting Theory: Rethinking Approaches to Cultures of Globalization. In B. S. Turner (Ed.), Routledge international handbook of globalization (pp. 23-41). London: Routledge.

Ritzer, G. (2003). Rethinking Globalization: Glocalization/Grobalization and Something/Nothing. Sociological Theory, 21(3), 193-209.

Robertson, R. (1992). Globalization. Social Theory and Global Culture. London: Sage.

Robertson, R. (1995). Glocalization: Time-space and Homogeneity-heterogeneity. In M. Featherstone et al (Eds.), Global Modernities (pp. 25-44). London: Sage.

Roudometof, V. (2016a). Glocalization: A Critical Introduction. London: Routledge. https://doi.org/10.1177/1368431015605443.

Roudometof, V. (2016b). Theorizing Glocalization: Three Interpretations. European Journal of Social Theory, 19(3), 391-408. https://doi.org/10.1177/1368431015605443

Saługa, P.W., Szczepańska-Woszczyna, K., Miśkiewicz, R., \& Chłąd, M. (2020). Cost of Equity of CoalFired Power Generation Projects in Poland: Its Importance for the Management of DecisionMaking Process. Energies, 13(18), 4833.https://doi.org/10.3390/en13184833

Savchenko, T., Basiurkina, N., Rodina, O., \& Kwilinski, A. (2019). Improvement of the Assessment Methods of Product Competitiveness of the Specialized Poultry Enterprises. Management Theory and Studies for Rural Business and Infrastructure Development, 41(1), 43-61. https://doi.org/10.15544/mts.2019.05 
Sharma, C. K. (2009). Emerging Dimensions of Decentralisation Debate in the Age of Globalisation. Indian Journal of Federal Studies, 1, 47-65. http://dx.doi.org/10.2139/ssrn.1369943

Shavkun, I.H. (2008). Menedzhment XXI stolittia: koliziia mizh hlobalizatsiieiu i rehionalizatsiieiu. Humanitarnyi visnyk Zaporizkoi derzhavnoi inzhenernoi akademii: Zb. nauk. pr., 35, 90-99. [in Ukrainian].

Shchetynin, A.I. (2011). Politychna ekonomiia. Pidruchnyk. Kyiv: Tsentr uchbovoi literatury. [in Ukrainian].

Sobolev, V. (2004). Tipy mezhdunarodnogo marketinga v usloviyah globalizatsii vneshnih ryinkov. [in Russian].

Spiegler, M. (2000). Glocalization: Easier Said Than Done. Retrieved from http://www. thestandard.com/article/display/0,1151,18890,00.html

Tkachenko, V., Kwilinski, A., Korystin, O., Svyrydiuk, N., \& Tkachenko, I. (2019a). Assessment of Information Technologies Influence on Financial Security of Economy. Journal of Security and Sustainability, 8(3), 375-385. http://doi.org/10.9770/jssi.2019.8.3(7)

Tkachenko, V., Kwilinski, A., Klymchuk, M., \& Tkachenko, I. (2019b). The Economic-Mathematical Development of Buildings Construction Model Optimization on the Basis of Digital Economy. Management Systems in Production Engineering, 27(2), 119-123. http://doi.org/10.1515/mspe2019-0020

Tkachenko, V., Kwilinski, A., Tkachenko, I., \& Puzyrova, P. (2019c). Theoretical and Methodical Approaches to the Definition of Marketing Risks Management Concept at Industrial Enterprises. Marketing and Management of Innovations, 2, 228-238. http://doi.org/10.21272/mmi.2019.2-20

Tkachenko, V., Kwilinski, A., Kaminska, B., Tkachenko, I., \& Puzyrova, P. (2019d). Development and Effectiveness of Financial Potential Management of Enterprises in Modern Conditions. Financial and Credit Activity: Problems of Theory and Practice, 3(30), 85-94. https://doi.org/10.18371/fcaptp.v3i30.179513

Tkachenko, V., Kuzior, A., \& Kwilinski, A. (2019e). Introduction of Artificial Intelligence Tools into the Training Methods of Entrepreneurship Activities. Journal of Entrepreneurship Education, 22(6), 110.

Yelnikova, Y., \& Miskiewicz, R. (2020). Implementation Mechanism of Impact Investing in the PostConflict Regions. Financial Markets. Institutions and Risks, 4(3), 53-65. https://doi.org/10.21272/fmir.4(3).53-62.2020

Zhukov S.A. (2010). Mekhanizmy zastosuvannia rehionalnoho marketynhu v systemi transkordonnoho ekonomichnoho spivrobitnytstva prykordonnoho rehionu (na materialakh Zakarpatskoi oblasti): monohrafiia. Mukachevo: V-tvo "Elara." [in Ukrainian]. 